\title{
СЕКРЕТИ ПОЕТИЧНОГО ТЕКСТУ Й ПОЕТИЧНОЇ МОВИ В НАУКОВИХ РЕФЛЕКСІЯХ ПРОФЕСОРА АНАТОЛІЯ МОЙСІЄНКА
}

\section{(Мойсієнко А. Текст як мистецька даність. Проблеми поетич- ної мови. Харків: Видавництво Іванченка I. С., 2018. 206 с.)}

«Поезія - це завжди неповторність», - так Ліна Костенко озвучила феномен поетичного твору як виду словесного мистецтва, як процесу й результату індивідуальної лінгвокреативної діяльності, що у своїх кращих зразках дорівнює інсайту - стану метафізичному, науково не пояснюваному й почасти незбагненному раціональною людською свідомістю. Вочевидь, цим поезія і приваблює вчених-філологів, які попри все прагнуть науково осмислити цей процес, зрозуміти сутність поетичного тексту й поетичної мови, виявити в них певні універсалії на рівні формально-семантичних ознак, дослідити мовні засоби сенсотворення, шляхи досягнення митцем художнього ефекту й тих емоційних відчуттів, що є зворотною реакцією читача на вірш. Це складне завдання, але тим і привабливіше для науковців від давніх часів до сьогодення: ідеї Аристотеля, висловлені в праці «Поетика», зазнали інтерпретацій у давніх поетиках, трудах О. Потебні, І. Франка, представників європейських лінгвістичних шкіл початку XX ст., у сучасних студіях з питань лінгвопоетики.

Рівень і характер наукових рефлексій щодо секретів поетичної творчості загалом і поетичного тексту зокрема різний і залежить не лише від обраної векторності досліджень, але й від особи самого дослідника. Раціональне наукове мислення вченого продукує багато інформації про структуру поетичного тексту як системи, про ії компоненти, зовнішньо-внутрішні зв'язки між ними, що вкрай важливо для опису мовних ресурсів та їхнього художнього потенціалу. Але досліднику, який сам є митцем і пише поезію, відкриється набагато більше - окрім здійснення суто лінгвістичного аналізу, він здатний зчитати глибшу інформацію, основою якої $є$ власна творча емпірика, що й уможливлює розуміння тонких сенсових та образних сутностей поетичної мови як феномену.

До таких науковців належить Анатолій Кирилович Мойсієнко, відомий мовознавець і поет, який послідовно в Україні розробляє 
питання лінгвопоетики, досліджуючи поетичний текст у його різних вимірах і характеристиках, намагаючись бути переконливим у висловлених теоретичних положенняхй представленій аналітиціконкретних зразків українського й світового (переклади) мистецтва слова. Тож поява книги «Текст як мистецька даність. Проблеми поетичної мови» (Харків, 2018) є логічним розгортанням проблематики попередніх монографій і статей автора щодо авторського ідіолекту, мовного новаторства, діалогічності поетичного тексту, унікальних жанрових форм поезії тощо. Саме ці аспекти репрезентують дослідницький доробок проф. Мойсієнка в царині лінгвопоетики й формують зміст книги за відповідними тематичними розділами: 1) Текст і ідіолект (I, II);2) Поетика жанрострофи. Візуальна поезія; 3 ) 3 перекладознавчої царини.

Починає книгу наукова студія «Поетика слова і тексту», де автор систематизує теоретичні положення лінгвопоетики, запропоновані свого часу відомими мовознавцями та літературознавцями щодо особливостей наукового вивчення художньої мови й художнього тексту, посилаючись на праці В. Виноградова, В. Григор'єва, В. Жирмунського, С. Єрмоленко, Р. Якобсона, О. Потебні, Я. Славінського, Г. Степанова, М. Храпченка та ін. Осмислюючи цей доволі вагомий доробок, автор зосереджується на такому важливому питанні, як предмет дослідження лінгвопоетики, адже ця галузь у своїх дослідницьких площинах інтегрує два складники - художній текст як витвір мистецтва й художню мову як засіб об’єктивації мистецького задуму автора.

Цілком переконливою є позиція проф. Мойсієнка про «потребу комплексного (філологічного) аналізу текстових структур, який і покликана здійснювати поетика, де не повинно існувати проблеми домінантного / периферійного щодо лінгвістичного чи літературознавчого». I далі: «Особливою метою кожного інтерпретатора текстової структури із засад поетики <...> має бути філологічне дослідження поетичної функції тих чи тих компонентів власне мовної, образносмислової, структурно-композиційної структури тексту, цілісного твору» (Мойсієнко, 2018: 6). Ця теза надто важлива для розуміння того, що саме є основною метою наукового вивчення художнього тексту, аби не зануритися в глибини лише лінгвістичного аналізу конкретних мовних одиниць чи явищ без урахування їхньої естетичної функції, власне того, що забезпечує творення художнього ефекту, відмежовуючи літературний текст від решти. Комплексність, цілісність, 
філологічність - ці ключові слова (наскрізні в настановах автора) мають спрямовувати векторність досліджень поетики художнього твору.

У своїх студіях проф. Мойсієнко з дотриманням окресленої методологійної траєкторії здійснює лінгвістичний аналіз поетичних текстів відомих українських митців - Тараса Шевченка, Олександра Олеся, Яра Славутича, Миколи Бажана, Емми Андієвської та інших. Що цікавить автора в художньому світі цих митців? На які важливі складники поетичної мови він звертає дослідницьку увагу? Ці питання знаходять відповідь у запропонованих розвідках, кожна з яких актуалізує певний лінгвопоетичний ракурс мовної картини письменника. Наприклад, у динамічній системі вірша Яра Славутича розглянуто тематико-композиційний і лексико-семантичний рівні текстової структури; у поемі Миколи Бажана «Політ крізь бурю» порушено питання експресивності й прокоментовано засоби іiі відтворення в тексті поеми; поетичне слово Шевченка досліджено у вимірі його новаторства, що постало як відбиття нового художнього мислення, перспективного й позачасового для національно-образної свідомості.

Для тих, хто знає мистецьку симпатію проф. Мойсієнка до творчості Емми Андієвської, очікуваною видається розвідка про «архітектурні ансамблі» письменниці, що, на думку автора, належить до тих «найяскравіших імен, які невтомно і самобутньо репрезентують нашу літературу на зарубіжних теренах» (Мойсієнко, 2018: 77). Предметом своїх рефлексій учений обрав формальний аспект сонетів поетеси, зокрема їхнє римування, що явно відходить від загальноприйнятих канонів, адже, на думку професора, «неканонічна сама природа поетичного творення Емми Андієвської, весь арсенал ії художньо-зображальних засобів (там само). Цікавими й переконливими з погляду органічного «поетичного чуття» $€$ тези автора про канонічність / неканонічнсть художнього мислення, яке набагато ширше й багатше устаткованих приписів. Чи можна вважати ганджем консонансне й асоціативне римування, властиве поетиці Емми Андієвської, на це риторичне питання $\epsilon$ відповідь: так само ганджем «може бути банальний образ, словесний штамп, <..> притягнута за вухо рима, незважаючи на те, точна вона чи ні». I як резюме: «Тут усе визначає майстерність. Авторська індивідуальність» (там само).

Ця домінанта $€$ посутньою для поета Анатолія Мойсієнка, який і сам творець художнього світу, індивідуально-неповторного, 
вибудованого за законами власних естетичних уподобань, підпорядкованих глибокому розумінню законів поетики, професійній майстерності філолога в роботі з мовою. Філологічна фаховість прозоріє не лише в здійсненні переконливого лінгвостилістичного аналізу поетичних контекстів, а й у ремарках та коментарях, адже за ними - розуміння художньо-естетичних шляхів, якими рухається національна й світова поезія, знання тих нюансів, що вирізняють конкретний поетичний текст 3-поміж інших на тлі часу та мистецької епохи.

Досліджуючи текстові утворення в художній мові, проф. Мойсієнко звертає увагу на хіазмічні конструкції, основою яких є синтаксична структура оберненого паралелізму (Минають дні, літа проходять), що в широку сенсі грунтується на понятті антиметаболи (Мойсієнко, 2018: 50). Про антитетичність як характерний маркер хіазму говорили свого часу М. Гаспаров та Е. Різель, проте найпосутнішою ознакою цієї стилістичної фігури, на думку автора, варто визначити зворотню послідовність членів у другому реченні поданої конструкції - синтаксичної структури $з$ двох сусідніх речень. Таке розуміння хіазму маємо в О. Квятковського, Л. Лонської, А. Загнітка та ін. I саме воно дає підстави професорові уналежнити хіазм до текстового утворення, репрезентованого на всіх синтаксичних рівнях: у системі простого речення, у структурі складносурядного й складнопідрядного речення, інших моделях. Свої теоретичні положення автор ілюструє численними контекстами, узятими з поетичного доробку українських митців слова, зокрема Є. Маланюка, В. Стуса, Л. Костенко, Є. Гуцала, В. Голобородька, О. Слоньовської та ін., переконуючи тим самим, що хіазми $є$ досить поширеними текстовими утвореннями в українській поетичній мові як граматичні явища в системі реченнєвої структури і як стилістичні явища в системі в межах тексту-речення (Мойсієнко, 2018: 54).

Анатолій Мойсієнко - представник сучасної модерної поезії, його тексти оригінальні в структурній організації і стилістиці, приваблюють буттєвою філософічністю та сенсовістю. Цю світогляднохудожню модерність професор екстраполює й у свій дослідницький дискурс, залучаючи до лінгвостилістичного аналізу нетиражовані в національній естетиці поетичні форми: тріолет, рондель, паліндром, візуальну й шахову поезію. Коментуючи недостатність поширення цих поетичних зразків в українській літературі, автор прагне 
хоча 6 наукової сатисфакції, присвятивши цим рідкісним художнім феноменам свої дослідницькі розвідки (розділ «Поетика жанрострофи. Візуальна поезія»). Цікавою й пізнавальною для дослідників поетичного мислення є стаття «Ронделевий вірш Миколи Бровка» про рондель та особливості його ліричної природи й побудови жанрострофи. Автор поступово вводить читача в історію й теорію ронделя, а далі розгортає лінгвопоетичний аналіз ронделевих текстів Миколи Бровка, акцентуючи не тільки авторську оригінальність їхьої структури, а й специфіку тематично-мотивного звучання. Ронделі цього поета - «не лише пейзажні замальовки чи інтимні мініатюри, а й соціально заангажований вірш, вірш-протест, вірш-інвектива» (Мойсієнко, 2018: 110).

Органічним явищем для української поезії проф. Мойсієнко вважає раковий вірш, або паліндром, історія якого сягає часів формування античного й надалі барокового мистецького мовомислення. Паліндром приваблює автора і як дослідницький матеріал, і як складне інтелектуально-художнє завдання для поета. У самого Анатолія Мойсієнка є цілий ряд паліндромів, що стали вже класичними для української поезії XX ст. (ця оригінальна творчість була активована засновниками літературного гурту «Геракліт» (1991), серед яких чільне місце посів Анатолій Мойсієнко). Основа паліндромного віршування, на думку гераклітівців, - звукосмислова просторовість українського слова, яке й співтворець, і співавтор. Саме це «співавторство рідної мови» - головна запорука того, що паліндром органічне явище для української поетичної думки, а не штучне ії конструювання. Для аргументації своїх тез автор наводить фрагменти з книг філолога XIX ст. Л. Лукашевича, що допомагають зрозуміти паліндромність у загальномовному контексті як свідчення «колосальних потенційних можливостей рідної мови», іï «творчої будівничої спромоги, незвичайної граматичної гнучкості й лексичного багатоманіття в освоєнні художньо-естетичних і загальнолюдських цінностей» (Мойсієнко, 2018: 123).

Найбільшої інтелектуальної напруги потребує такий феномен, як шахопоезія, що «синтезує в собі власне поетичне й шахове начала», де шаховий компонент репрезентований сферою композиції (Мойсієнко 2018: 141). Проф. Мойсієнко - ідеолог шахової поезії в українському мистецтві слова, йому належать два розроблених эї різновидів, 
опис і презентація яких репрезентовані в розвідці «Поетика шахової задачі. Шахопоезія». Вражає шахова компетентність автора, його потужний інтелект і креативність мислення, здатного синтезувати два складних явища - шахові композиції й скорельований з ними поетичний текст (це, зокрема, поезії «Правда в тому» й «Легкого не вибираємо»). Оптимістичним для автора є те, що в жанрі шахопоезії «сьогодні працює чимало інших українських митців, які знаходять нові підходи до осмислення цього мистецького жанру». Наприклад, Віктор Капуста, що видав 2003 р. збірку «Крилатий материк», уперше ввівши в художній обіг жанр шахосонета (Мойсієнко, 2018: 145).

Завершує книгу розділ «3 перекладознавчої царини», де вміщений лінгвопоетичний аналіз східнослов'янських перекладів поезій Тараса Шевченка та Івана Франка, українських перекладів світових і білоруських сонетів, творів Адама Міцкевича, Р.-М. Рільке та інших авторів. Проф. Мойсієнко приєднується до тих фахівців, хто уналежнює кращі перекладні тексти до надбань національної культури, мовою якої здійснені ці переклади. Адже в перекладах випробовується лінгвостилістичний потенціал цієї мови, іiї здатність адаптувати під питомі лексико-граматичні структури закладені іномовним автором форму й смисл тексту-оригіналу. В оцінюванні художньої вартості перекладних текстів проф. Мойсієнко звертає увагу й на ряд екстралінгвальних чинників, зокрема особистісні й суб'єктивні нюанси, але головне - це «чистота» праці перекладача, що не мислима без глибинного входження в авторський текст, розуміння найменших його нюансів» (Мойсієнко, 2018: 162). Саме таких позицій дотримується Анатолій Мойсієнко, талановито перекладаючи української мовою поезії російських, білоруських, польських, чеських, словацьких, німецьких поетів ${ }^{1}$.

Підсумовуючи написане, варто сказати й про наратив наукового студіювання проф. Мойсієнком поетичного доробку обраних митців, стиль і характер текстової об’єктивації здійсненого лінгвопоетичного аналізу. Відчутним $є$ те, що автор орієнтується на читача, який візьме до рук його книгу й, прочитавши перші сторінки, захоче далі поринути у світ краси й витонченої естетики українського поетичного мовлення. Усе підпорядковано цій інтенції: доступність і стрункість наукового викладу, розтлумачення літературознавчих і лінгвістичних

1 Див. книгу: Мойсієнко, А (2018). Синьоліт ліхтарів синьоирій: книга сонетів. Київ: Щек. 
понять для кращого входження читача в тему, оригінальні жанри й тексти, доречні приклади з поезій, переконливий список наукових джерел як теоретичне підгрунтя для власних рефлексій. I відчуття свого читача, до якого звернені міркування автора про минуле, теперішнє й майбутнє української поезії, про перспективи їі художньомовного й інтелектуального ресурсу, про загальнокультурну вартість літератури в людському бутті. Видається, що книга відбулася як цікавий аналітично-дослідницький проєкт з лінгвопоетики, цілком органічної для української філологічної науки від праць їі фундаторів й до сьогоденних прагнень пізнати феномен поетичної творчості як мистецтва красного слова.

\section{ЛІТЕРАТУРА}

1. Мойсієнко, А. (2018). Текст як мистецька даність. Проблеми поетичної мови. Харків: Видавництво Іванченка I. С.

\section{REFERENCES}

1. Moisiienko, A. (2018). Tekst yak mystetska danist. Problemy poetychnoi movy [The text as an artistic fact. Problems of poetic language]. Kharkiv: Vydavnytstvo Ivanchenka I. S. [in Ukrainian].

Маленко Олена Олегівна - доктор філологічних наук, професор, завідувач кафедри українознавства і лінгводидактики, Харківський національний педагогічний університет імені Г. С. Сковороди; вул. Валентинівська, 2, Харків, 61168, Україна.

Tel.: +38 067-938-86-57

E-mail: malena-o@yandex.ua

https://orcid.org/0000-0003-4753-0036

Malenko Olena Olehivna - Doctor of Philological Sciences, Professor, Head of the Department of Ukrainian Studies and Applied Linguistics, H. S. Skovoroda Kharkiv National Pedagogical University; Valentynivska Str., 2, Kharkiv, 61168, Ukraine.

Надійшла до редакції 02 серпня 2020 року

\section{CITATION}

ДСТУ 8302:2015: Маленко О. О. Секрети поетичного тексту й поетичної мови в наукових рефлексіях професора Анатолія Мойсієнка. Рец. на моногр.: Мойсієнко А. Текст як мистецька даність. Проблеми поетичної мови. Харків: Видавництво Іванченка I. C., 2018. 206 с. Лінгвістичні дослідження: зб. наук. пр. Харк. нац. пед. ун-ту імені Г. С. Сковороди. Харків, 2020. Вип. 53. С. 269-275. DOI: https://doi.org/10.34142/ 23127546.2020.53.25

APA: Маленко, О. О. (2020). Секрети поетичного тексту й поетичної мови в наукових рефлексіях професора Анатолія Мойсієнка. Рец. на моногр.: Мойсієнко А. Текст як мистецька даність. Проблеми поетичної мови. Харків: Видавництво Іванченка I. C., 2018. 206 с. Лінгвістичні дослідження, 53, 269-275. DOI: https://doi.org/ $10.34142 / 23127546.2020 .53 .25$ 